\title{
Tingkat Penerimaan User pada Sistem Informasi Inventory di Badan Usaha Mikro Kecil dan Menengah
}

\author{
HERDI ASHAURY ${ }^{1}$, RIVAL MUHAMAD SAEPULOH ${ }^{2}$, CHRISTINE CHLYW \\ NOVA $^{3}$
}

1,2,3 Universitas Jenderal Achmad Yani

Email: herdi.ashaury@lecture.unjani.ac.id

\begin{abstract}
ABSTRAK
Oishii Organic Chicken adalah salah satu UMKM di bidang kuliner yang mengalami masalah pada pencatatan data barang, dimana stok yang tersisa sering tidak sesuai dengan catatan yang ditulis oleh karyawannya. Hal tersebut dapat menjadi kerugian bagi Oishii Organic Chicken. Profit yang didapat dari badan usaha UMKM tidak sebesar dengan profit yang didapat oleh perusahaan skala besar. Oleh karena itu, penting sekali untuk mengelola data barang yang masuk dan keluar untuk menjamin profit yang didapat, bisa terserap secara maksimal dan mengembangkan usaha lebih baik lagi. Sistem inventori adalah salah satu sistem informasi untuk untuk mengelola persediaan barang di gudang. Sistem ini digunakan untuk melihat data perubahan pada stok barang saat melakukan penambahan stok ataupun pengurangan stok barang. Pada penelitian ini akan melihat tingkat penerimaan User dalam penerapan pembangunan sistem informasi inventory di suatu badan usaha kecil dan menengah dengan studi kasus di Oishii Organic Chicken.
\end{abstract}

Kata kunci: Sistem Informasi Inventory, UMKM.

\begin{abstract}
Oishii Organic Chicken is one of the MSMEs in the culinary field that has problems recording item data, where the remaining stock often does not match the records written by its employees. This can be a loss for Oishii Organic Chicken. Profits obtained from MSME business entities are not as big as the profits obtained by large-scale companies. Therefore, it is very important to manage the data of incoming and outgoing goods to ensure that the profits obtained can be maximally absorbed and develop the business even better. Inventory system is one of the information systems for managing inventory in the warehouse. This system is used to view data on changes in stock of goods when adding stock or reducing stock of goods. In this study, we will develop an inventory information system in a small and medium business entity with a case study on Oishii Organic Chicken.
\end{abstract}

Kata kunci: Inventory Information System, UMKM. 


\section{PENDAHULUAN}

Perkembangan teknologi saat ini begitu cepat, dengan penggunaan teknologi informasi, tidak hanya dapat memperoleh data dan informasi dengan mudah dan cepat, namun keakuratan data juga harus diperhatikan (Tamodia, 2017). Keakuratan data dan informasi barang pada proses produksi sangat penting karena akan dijadikan sebuah pelaporan informasi pembukuan. Sistem yang terkomputerisasi dapat menjaga keakuratan data diperlukan dengan lebih baik (Tamodia, 2017). Selain itu, Persaingan dalam dunia usaha pada era sekarang ini semakit ketat dan bersaing, khususnya pada usaha penjualan barang. Pelaku usaha harus menerapkan starategi bisnis dan memberikan layanan terbaik untuk mempertahankan usahanya terutama untuk kelas kecil dan menengah.

Inventory atau Persediaan didefinisikan sebagai barang, bahan-bahan, atau asset yang dimiliki oleh perusahaan untuk digunakan di masa yang akan dating (B. U. Fahnun, 2016). Kebijakan di bidang persediaan dapat dipandang sebagai masalah taktis (tactical problem), sehingga perencanaan kebutuhan persediaan direncanakan dalam kontek jangka waktu menengah selaras dengan keseluruhan rencana produksi, strategi pemasaran dan distribusi. Inventory adalah persediaan dari item apapun atau sumber daya yang digunakan dalam suatu organisasi atau perusahaan. Persediaan pada umumnya merupakan salah satu jenis aktiva lancar yang jumlahnya cukup besar dalam suatu perusahaan (B. U. Fahnun, 2016).

Ketersediaan produk dan bahan baku sangat perlu untuk di perhatikan untuk memenuhi permintaan pasar. Seringkali ketersediaan bahan baku dan produk menyebabkan terjadinya lost of sale, yang mengakibatkan hilangnya penghasilan yang mungkin di peroleh. Salah satu cara untuk mengelola ketersedian produk/barang dengan dengan menerapkan sistem iventory barang (B. U. Fahnun, 2016) (M. L. Hamzah, 2017). Persediaan barang (Inventory) atau penyimpanan barang, dalam konteks produksi merupakan hal yang sangat dibutuhkan pada perusahaan yang melakukan proses produksi. Sistem pencatatan barang merupakan kegitan yang terkoputerisasi untuk melakukan pencatatan bahan-bahan, atau asset yang dimiliki oleh perusahaan untuk digunakan di masa yang akan dating (M. L. Hamzah, 2017). Kebijakan di bidang persediaan dapat dipandang sebagai masalah taktis (tactical problem), sehingga perencanaan kebutuhan persediaan direncanakan dalam kontek jangka waktu menengah selaras dengan keseluruhan rencana produksi, strategi pemasaran dan distribusi (M. L. Hamzah, 2017).

Permasalahan ketersediaan produk juga dialami pada pelaku usaha skala micro, kecil dan menengah (UMKM). Salah satunya pada UMKM Oishii Organic Chicken, dimana sering terjadi kesalahan dan manipulasi pada pencatatan keluar masuk barang. Selaini itu, perhitungan stok barang yang masih dilakukan tanpa komputerisasi yang mengakibatkan terjadinya penimbunan dan ketidak tersdian bahan baku dan barang. Tidak hanya itu, pada Oishii organic chiken juga sering terjadi kesalahan dan kehilangan list pembelian bahan baku yang tidak sesuai karena masih menggunakan media cetak yang mengakibatkan kehilangan atau kerusakan catatan, sehingga bahan baku sering tidak terkirim.

Pembuatan perangkat lunak dapat mengatasi solusi dari permasalah bisnis. Namun pengembangan perangkat lunak, bisa menjadi tidak tepat guna, jika tidak dikembangkan dengan baik. Beberapa metode evaluasi, dapat digunakan untuk mengetahui penerimaan dari suatu perangkat lunak. Salah satunya adalah menggunakan User Acceptance Test (UAT) (Suprianto, 2018). Pada penelitian ini akan mencoba untuk membuat suatu system inventory untuk mengatasi masalah ketersediaan bahan baku diatas, dan menguji seberapa jauh system yang buat, dapat memenuhi atau menyelesaikan permasalahan yang ada di Oishii Organic Chicken dengan menggunakan User Acceptance Test. 


\section{METODE PENELITIAN}

Tahapan dalam penelitian ini adalah dengan melakukan Analisa kebutuhan perangkat lunak, perancangan perankat lunak, implementasi perangkat lunak, pengujian perangkat lunak.

\section{Analisa kebutuhan}

pengumpulan data-data berupa kebutuhan menganai sistem yang akan dibangun, dilakukan dengan wawancara dan observasi langsung kepada pihak yang bersangkutan, wawancara dilakukan sebanyak 3 kali setiap wawancara yang dilakukan membutuhkan waktu 3-4 jam. Dari hasil wawancara pada Oishii Organic Chicken yang dilakukan diperoleh Kebutuhan sitem yang akan di bangun.

\section{Perancangan Perangkat Lunak}

Dari hasil analisa kebutuhan, dibuat perancangan berupa tampilan sistem (User interface) dan diagram-digram dari proses bisnis yang akan di bangun.

\section{Implementasi Perangkat Lunak}

Setelah proses perancangan telah sesuai dengan kebutuhan pengguna, baru dilakukan tahap pengkoden sistem menggunakan Basaha Pemograman PHP dengan framework laravel.

\section{Pengujian Perangkat Lunak}

Pegujian sistem yang dilakukan dengan melakukan pengujian blackbox testing untuk mengetahui aplikasi sudah bebas dari error, dan user acceptance test setelah pengguna yang akan menggunakan sistem pada Oishii Organic Chicken. Dari hasil pengujian sistem didapatkan perbaikan mengenai fungsi yang belum berjalan sebagai mana mestinya.

\section{HASIL DAN PEMBAHASAN}

\subsection{Analisis Kebutuhan Perangkat Lunak}

Sebelum melakukan perancangan sistem, langkah yang dilakukan terlebih dahulu adalah menganalisa proses bisnis yang terjadi di UKM OISHII Organik Chiken. UKM tersebut Belum memiliki sistem informasi semua tahap masih dilakukan secara manual Sistem yang sedang berjalan saat ini ketika admin ingin membeli stok bahan baku di gudang, admin harus terlebih dahulu menegecek ke gudang dan menghitung jumlah stok. Setelah itu baru admin akan melist barang yang kan di beli dari vendor lalu vendor akan mengirimkan pesanan bahan baku, selanjutnya admin akan mengecek bahan baku lalu melakukan pembayaran dan admin akan melakkan pencatatan barang masuk pada buku catatan.

Barang yang masuk kemudian akan diolah oleh admin lalu akan dikirimkan ke Karyawan kemuadian Karyawan akan mengolah bahan baku menjadi barang jadi. Pembelian barang dilakukan dengan pembeli melist barang yang akan di beli kemuadian meyerahkannya kepada Karyawan, selanjutnya Karyawan akan menyiapkan pesanan dan menhitung total biaya selanjutnya pembeli membayar dan Karyawan akan menyerahkan butik pembayaran. Selanjutnya Karyawan akan mecatat dalam buku catatan deskripsi barang yang terjual setiap satu kali transaksi penjualan.

Berdasarkan proses bisnis diatas, dapat dirumuskan beberapa actor yang akan terlibat dalam proses pencatatan barang keluar masuk. Aktor-aktor sebagai calon pengguna sistem dapat 
dilihat pada tabel 1. Sedangkan untuk kebutuhan fungsional yang dibutuhkan untuk menyelesaikan permasalahan, dapat dirumuskan dengan tabel 2 .

Tabel 1. Pengguna Sistem

\begin{tabular}{|c|c|}
\hline Aktor & Wewenang dan Tugas \\
\hline Administrator & $\begin{array}{c}\text { Melakukan kelola Data Barang, Kelola Pejukan, } \\
\text { Kelola Tagihan, Kelola Produksi }\end{array}$ \\
\hline Karyawan & $\begin{array}{c}\text { Melakukan Kelola Pejualan dan Tambah Produksi } \\
\text { Barang }\end{array}$ \\
\hline
\end{tabular}

Tabel 2. Pengguna Sistem

\begin{tabular}{|c|c|c|}
\hline No. & Kebutuhan Fungsional & Deskripsi \\
\hline 1. & Mengelola Satuan & User dapat menambah, mengubah dan menghapus \\
data satuan barang.
\end{tabular}

Use Case Diagram menggabarkan aktor yang berinteraksi dengan sistem, dibuat sesuai dengan proses bisnis yang telah diidentifikasi dari analisi sistem berjalan (Sommerville, 2010). Use Case Diagram digambarkan dengan aktor dan use case. Aktor yang menggambarkan siapa saja yang terlibat dalam sistem, sedangkan use case menggambarkan sistem atau fungsi pada perangkat lunak. Pemodelan perangkat lunak. Pemodelan use case mendefinisikan kebutuhan fungsional dari sistem. Use Case Diagram Sistem Informasi Pencatatan Keluar Masuk Barang UKM Oishii Organic Chicken ditujukan pada Gambar 1. 
Pembangunan Sistem Informasi Inventory di Badan Usaha Mikro Kecil dan Menengah

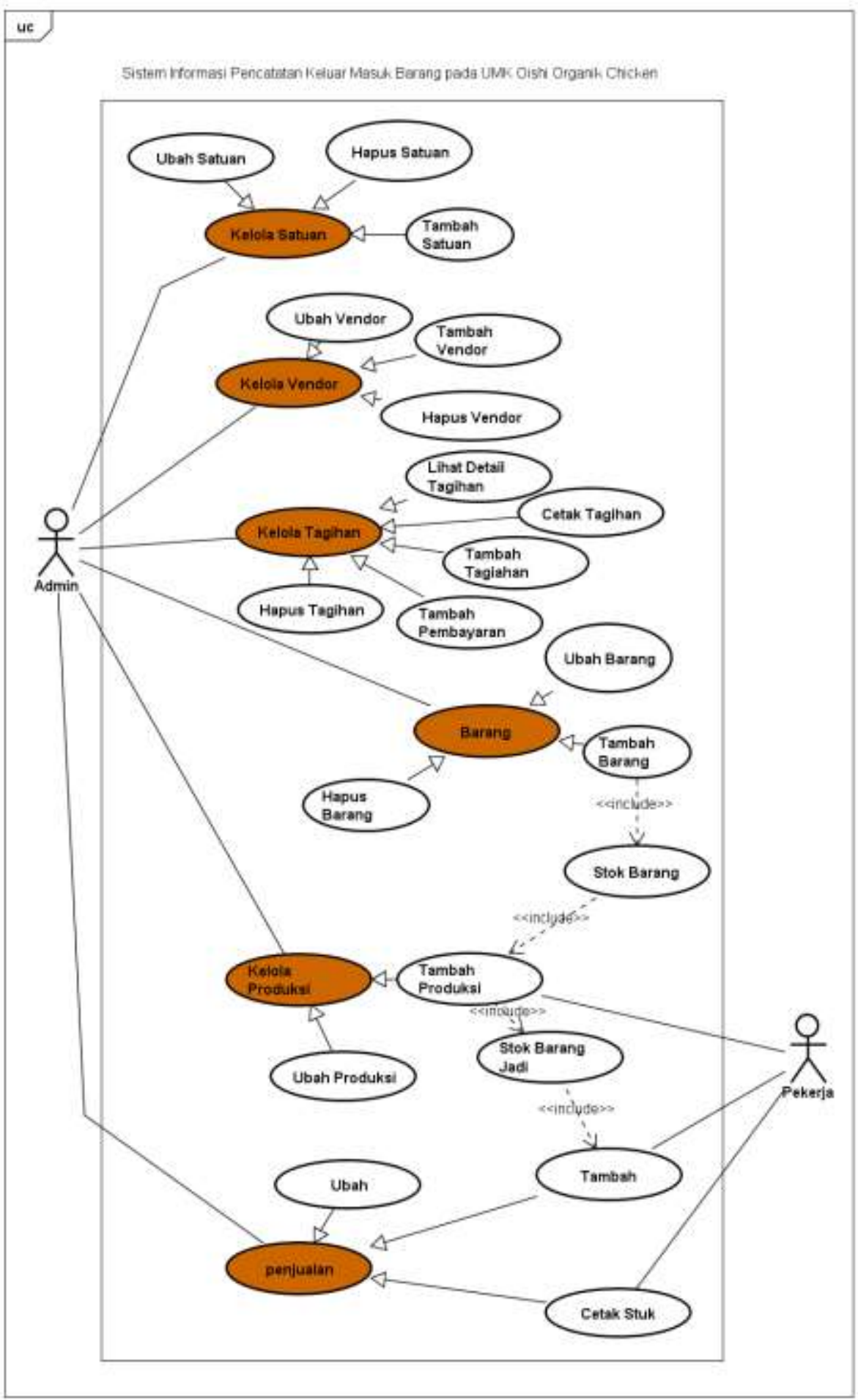

Gambar 1. Use Case Diagram

Class Diagram adalah diagram UML yang menggambarkan kelas-kelas dalam sebuah sistem dan hubungannya antara satu dengan yang lain, serta dimasukkan pula atribut dan method (Pressman, 2009). Class diagram untuk aplikasi yang akan dibangun, dapat dilihat pada gambar 2. 


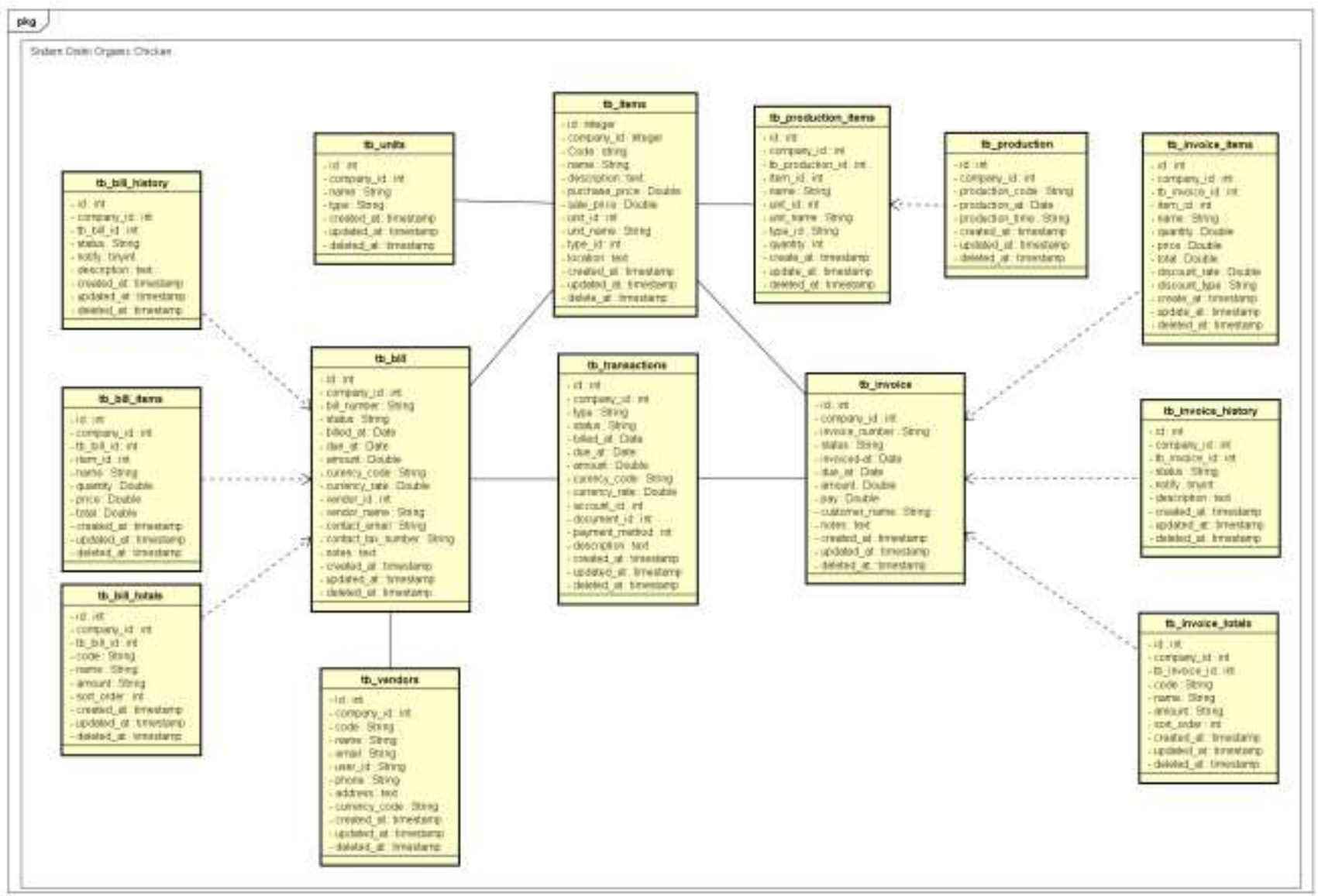

Gambar 2. Class Diagram

3.2. Implementasi dan Pengujian Perangkat Lunak Hasil analisis dan perancangan pada pembahasan sebelumnya, diimplementasikan sehingga menghasilkan tampilan antarmuka. Hasil implementasi dapat dilihat pada Tabel X.

Tabel 3. Hasil Implementasi

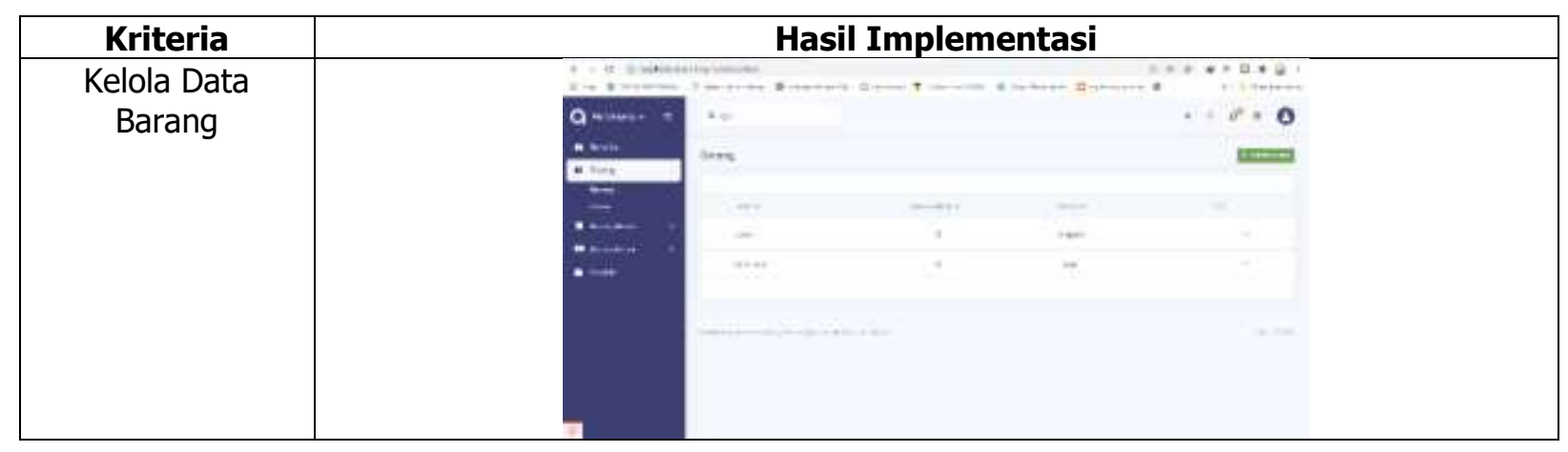


Pembangunan Sistem Informasi Inventory di Badan Usaha Mikro Kecil dan Menengah

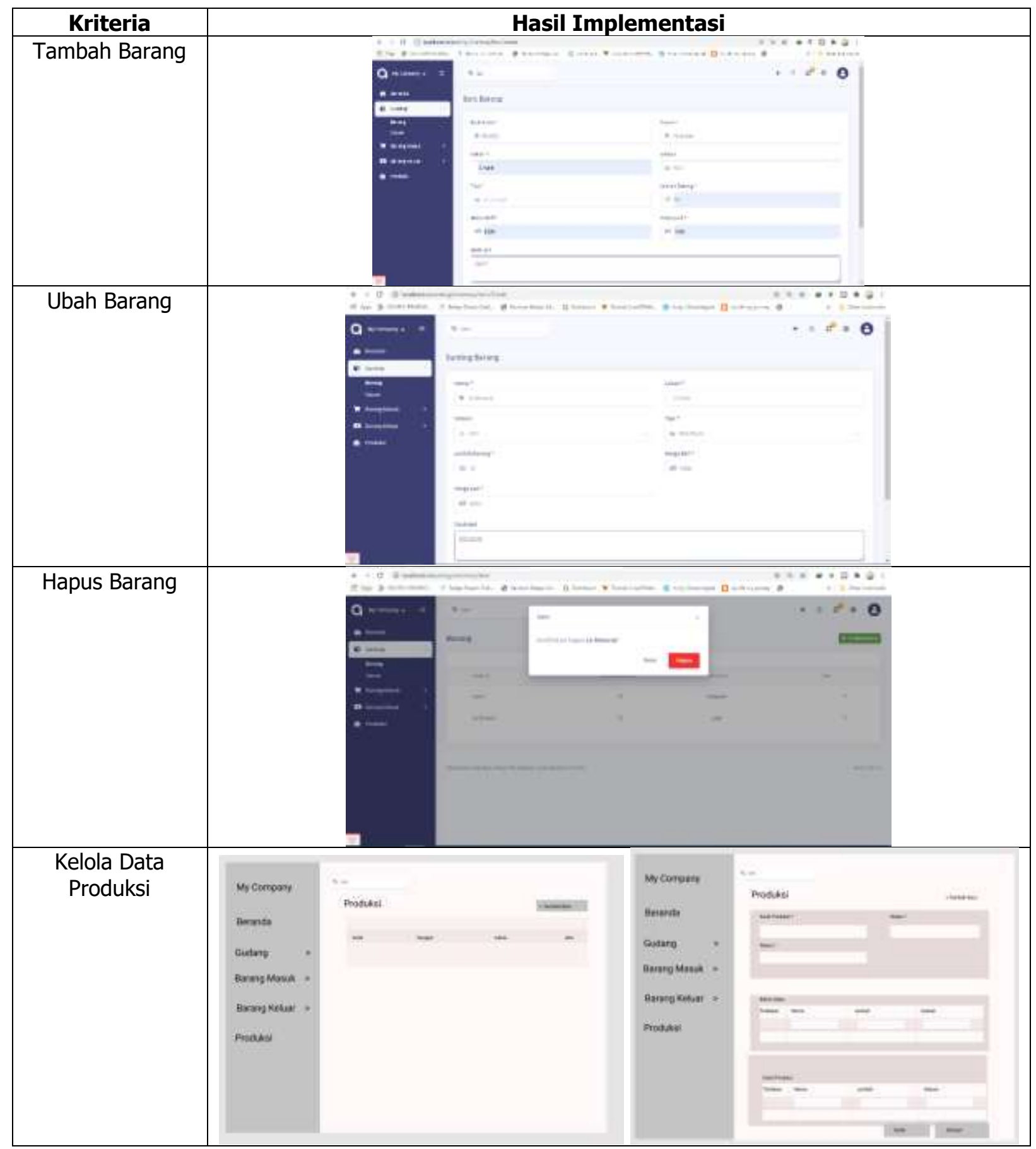




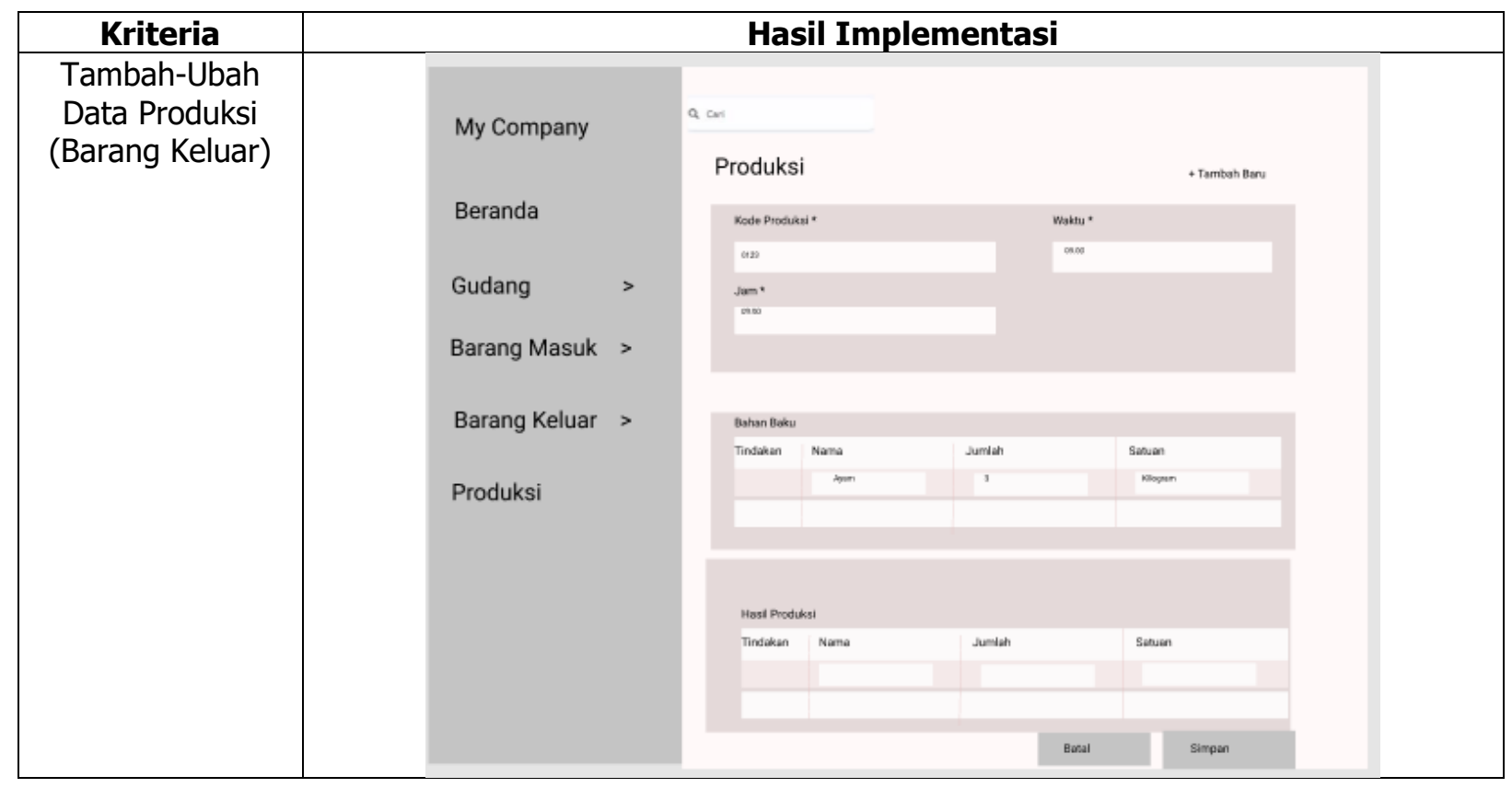

Untuk memastikan aplikasi bebas dari kesalahan, dilakukan pengujian menggunakan metode black box. Skenario pengujian perangkat lunak, dapat dilihat pada tabel 4 .

Tabel 4. Skenario Pengujian

\begin{tabular}{|c|c|c|c|}
\hline Proses & $\begin{array}{c}\text { Nama } \\
\text { Fungsi }\end{array}$ & $\begin{array}{c}\text { Kode } \\
\text { Uji }\end{array}$ & Kasus Uji \\
\hline $\begin{array}{c}\text { Kelola } \\
\text { Barang }\end{array}$ & Tambah & KU001 & Pilih menu barang, selanjutnya isi form yang tersedia data akan \\
di
\end{tabular}


Pembangunan Sistem Informasi Inventory di Badan Usaha Mikro Kecil dan Menengah

\begin{tabular}{|c|c|c|c|}
\hline Proses & $\begin{array}{l}\text { Nama } \\
\text { Fungsi }\end{array}$ & \begin{tabular}{|c|} 
Kode \\
Uji
\end{tabular} & Kasus Uji \\
\hline \multirow[t]{2}{*}{$\begin{array}{l}\text { Kelola } \\
\text { Produksi }\end{array}$} & Tambah & KU010 & $\begin{array}{l}\text { Pilih menu produksi, selanjutnya isi form yang tersedia data } \\
\text { akan di } \\
\text { simpan sementara. }\end{array}$ \\
\hline & Ubah & KU011 & $\begin{array}{l}\text { Pilih menu produksi, selanjutnya isi } \\
\text { form yang tersedia data akan di simpan sementara. }\end{array}$ \\
\hline \multirow[t]{5}{*}{$\begin{array}{l}\text { Kelola } \\
\text { Tagihan }\end{array}$} & Tambah & KU012 & $\begin{array}{l}\text { Pilih menu tagihan, selanjutnya isi } \\
\text { form yang tersedia data akan di simpan sementara. }\end{array}$ \\
\hline & $\begin{array}{c}\text { Tambah } \\
\text { Pembayaran }\end{array}$ & KU013 & $\begin{array}{c}\text { Pilih menu tagihan, lalau klik kode tagihan yang akan di bayara } \\
\text { selanjutnya isi form yang tersedia data } \\
\text { akan di simpan sementara }\end{array}$ \\
\hline & $\begin{array}{l}\text { Lihat Detail } \\
\text { tagihan }\end{array}$ & KU014 & $\begin{array}{l}\text { Pilih menu tagihan, selanjutnya pilih } \\
\text { koode data tagihan yang kan dilihat detailnya }\end{array}$ \\
\hline & Hapus & KU015 & $\begin{array}{c}\text { Pilih menu tagihan, selanjutnya hapus data pada form yang } \\
\text { tersedia, data } \\
\text { akan disimpan sementara }\end{array}$ \\
\hline & Cetak & KU016 & $\begin{array}{c}\text { Pilih menu tagihan,plih kode penjulan yang ingin } \\
\text { di cetak. selanjutnya cetak tagihan }\end{array}$ \\
\hline \multirow[t]{3}{*}{$\begin{array}{l}\text { Kelola } \\
\text { Penjulan }\end{array}$} & Tambah & KU017 & $\begin{array}{c}\text { Pilih menu penjualan, selanjutnya isi } \\
\text { form yang tersedia data akan di simpan sementara. }\end{array}$ \\
\hline & Ubah & KU018 & $\begin{array}{l}\text { Pilih menu penjualan, selanjutnya isi form yang tersedia data } \\
\text { akan di } \\
\text { simpan sementara. }\end{array}$ \\
\hline & Cetak & KU019 & Pilih menu $\begin{array}{c}\text { penjualan, } \\
\text { selanjutnya cetak struk. }\end{array}$ kode penjulan \\
\hline
\end{tabular}

Berdasarkan dari hasil pengujian menggunkan blackbox testing pada Sistem Informasi Pencatatan Keluar Masuk Barang Pada UKM Oishii Organic Chicken, maka dapat dihitung persetase kesesuain sistem dengan fungsionalitas sebagai berikut:

Jumlah kode uji $=19$

Kode uji dengan hasil sesuai $=17$

Kode $u j i$ dengan hasil tidak sesuai $=2$

Persentase kesesuaian

$$
\begin{gathered}
\text { Presentase }=\frac{\text { (jumlah kode uji }- \text { kode uji tidak sesuai) }}{\text { (Jumlah kode uji) }} \times 100 \% \\
=\frac{(19-2)}{(19)} \times 100 \% \\
=89.47 \%
\end{gathered}
$$

Hasil implementasi perangkat lunak, diterapkan dan dijalankan ditempat usaha, kemudian dilakukan pengujian penerimaan kepada user menggunakan metode User Acceptance Test. UAT dilakukan dengan melakukan survey ke pegawai di Oishii Chicken. Instrument Pengujian dirumuskan menjadi beberapa butir pertanyaan. Instrumen pengujian dapat dilihat pada tabel 5. Kesimpulan hasil pengujian UAT dapat dilihat pada tabel 6 . 
Tabel 1. Instrumen Pengujian UAT

\begin{tabular}{|c|c|c|c|c|}
\hline \multirow{2}{*}{ No. } & \multirow{2}{*}{ Pertanyaan } & \multicolumn{3}{|c|}{ Penilaian } \\
\hline & & \begin{tabular}{|l|l|l|}
1 & 2 & \\
\end{tabular} & \begin{tabular}{|l|l}
3 \\
\end{tabular} & 4 \\
\hline \multicolumn{5}{|c|}{ Aspek sistem } \\
\hline 1. & Apakah tampilan sistem pencatatan keluar masuk barang mudah di operasikan? & & & \\
\hline 2. & $\begin{array}{l}\text { Apakah alur sitem pencatatan keluar masuk barang telah merepresentasikan } \\
\text { proses pecatatan keluar masuk barang? }\end{array}$ & & & \\
\hline 3. & $\begin{array}{l}\text { Apakah fitur-fitur pada sistem pencatatan keluar masuk barang telelah sesuai } \\
\text { dengan keinginan user? }\end{array}$ & & & \\
\hline 4. & Apakah fungsi yang diinputkan telah sesuai dengan Output? & & & \\
\hline \multicolumn{5}{|c|}{ Aspek Pegguna } \\
\hline 5. & $\begin{array}{l}\text { Apakah dalam menggunakan pencatatan keluar masuk barang dapat ini } \\
\text { memberikan pengalaman yang baik? }\end{array}$ & & & \\
\hline 6. & $\begin{array}{l}\text { Apakah pencatatan keluar masuk barang ini dapat membantu dalam segi } \\
\text { efisiensi waktu pengelolaan barang? }\end{array}$ & & & \\
\hline 7. & $\begin{array}{l}\text { Apakah fitur-fitur pada sistem pencatatan keluar masuk barang ini mudah } \\
\text { dipahami oleh user? }\end{array}$ & & & \\
\hline \multicolumn{5}{|c|}{ Aspek Interaksi } \\
\hline 8. & $\begin{array}{l}\text { Apakah dalam mengoperasikan istem pencatatan keluar masuk barang } \\
\text { ditemukan error? }\end{array}$ & & & \\
\hline 9. & $\begin{array}{l}\text { Apakah dalam sistem pencatatan keluar masuk barang ini user dapat mengatasi } \\
\text { masalah yang ditemukan dengan mudah? }\end{array}$ & & & \\
\hline 10. & $\begin{array}{l}\text { Apakah fungsi-fungsi pada sistem pencatatan keluar masuk barang ini } \\
\text { memberikan respon sistem yang telah sesuai? }\end{array}$ & & & \\
\hline
\end{tabular}

Tabel 6. Hasil Kesimpulan UAT

\begin{tabular}{|c|c|c|c|c|}
\hline & Jumlah & Jumlah/Responden & $\%$ & $\begin{array}{l}\text { Rata- } \\
\text { Rata }\end{array}$ \\
\hline \multicolumn{5}{|c|}{ Aspek Sistem } \\
\hline 1 & 11 & 3.66 & $91 \%$ & \multirow[t]{4}{*}{$89.25 \%$} \\
\hline 2 & 10 & 3.33 & $83 \%$ & \\
\hline 3 & 12 & 4 & $100 \%$ & \\
\hline 4 & 10 & 3.33 & $83 \%$ & \\
\hline \multicolumn{5}{|c|}{ Aspek Pengguna } \\
\hline 5 & 12 & 4 & $100 \%$ & \multirow[t]{3}{*}{$97 \%$} \\
\hline 6 & 12 & 4 & $100 \%$ & \\
\hline 7 & 11 & 3.66 & $91 \%$ & \\
\hline \multicolumn{5}{|c|}{ Aspek Interaki } \\
\hline 8 & 8 & 2.22 & $66 \%$ & \multirow[t]{3}{*}{$76.66 \%$} \\
\hline 9 & 10 & 3.33 & $83 \%$ & \\
\hline 10 & 9 & 3 & $75 \%$ & \\
\hline
\end{tabular}

\section{KESIMPULAN}

Berdasarkan hasil pengujian, didapat rata-rata untuk aspek sistem diketaui sebesar $89.25 \%$ menyatakan setuju bahwa secara pengembangan sistem pencatatan keluar masuk barang memiliki tampilan sistem yang mudah dioperasikan, fitur-fitur dapat dioperasikan dengan baik, dan fungsi yang diiputkan telah sesui dengan output. Untuk Aspek pengguna di peroleh rata-ratanya $97 \%$ hal ini menyatakan sistem dapat memberikan pengalaman yang baik, dapat mengefisiensi kan waktu pelayanan, serta fitur-fitur mudah dipahami. Sedangkan untuk aspek Interaksi diketahui rata-ratany adalah $76.66 \%$ yang menyatakan sisiten telah memberikan respon yang sesuai dari fitur-fiturnya serta pengguna dapat menangani masalah 
yang ditemukan pada sistem dengan mudah. Sehingga sistem informasi inventori ini dapat memberikan kemudahan dalam pengelolaan stok data barang serta mengawasi data keluar masuknya barang.

\section{DAFTAR RUJUKAN}

B. U. Fahnun, H. D. (2016). Perancangan Sistem Inventory Berbasis Web (Studi Kasus PT. Continental Panjipratama). J. IIm. FIFO, 1-7.

M. L. Hamzah, A. A. (2017). Sistem Manajemen Inventori Komputer Menggunakan Near Field Communication Berbasis Android Studi Kasus di STIE Pelita Indonesia Pekanbaru. J. Econ. Bussines Account, 95-104.

Pressman, R. (2009). Software Engineering: A Practitioner's Approach. USA: McGraw-Hill, Inc.

Sommerville, I. (2010). Software Engineering. USA: Addison-Wesley Publishing Company.

Suprianto, R. A. (2018). Analisis Hasil Pemanfaatan Media Pembelajaran Interaktif Aljabar Logika Dengan User Acceptance Test (UAT). Malang: STIKI.

Tamodia. (2017). Rancang Bangun Sistem Informasi Persediaan Barang Berbasis Web Dengan Metode Fast(Framework For The Applications). J. PILAR Nusa Mandiri, 261266. 